\title{
Book Review: Privacy and Confidentiality Issues: A Guide for Libraries and Their Lawyers
}

Published May 7, 2009 Book Reviews Leave a Comment

Privacy and Confidentiality Issues: A Guide for Libraries and Their Lawyers.

98 pages, 2009, soft cover, American Library Association (ALA)

The privacy and confidentiality of library patrons concerned many public libraries after September 11, particularly because of the passage and enforcement of the Patriot Act. Theresa Chmara, a litigator who has represented the American Library Association, the Freedom to Read Foundation, and the American Bookseller's Association, provides concise and useful guidelines for libraries about these and other related issues in Privacy and Confidentiality Issues: A Guide for Libraries and Their Lawyers. This work is highly recommend for public library directors but should be required professional reading for all library directors. Additionally, library schools, which have an obligation to educate future librarians about the First Amendment concept of privacy in the context of the library, should purchase this book. It also serves as a great edition to a law school's First Amendment collection for the same reasons as well as to bolster an academic collection that may lack practice oriented sources in this area.

Chmara's text is well organized utilizing a question and answer format. This format makes it an ideal reference source. The chapters are also structured logically around issues facing libraries: instances where privacy and confidentiality conflicts arise, the First Amendment, privacy and confidentiality in the context of the Internet, relevant state statutes dealing with privacy, minors rights to privacy under the First Amendment, federal statutes, and the development of library privacy policies. The beginning of the book offers an overview of basic First Amendment principles. This is a thorough discussion and includes the definition of a public forum and how public libraries fit into the same doctrine (as a designated public forum), the right to receive information, restrictions that libraries can lawfully impose, and the legal tests and standards applicable to libraries. Of potential usefulness, Chmara explains how a library's legal counsel should research and prepare responses to the government intrusion on a library's privacy rights.

This work also underscores concepts of criminal procedure laws and principles as they apply to libraries. Specifically, in the chapter devoted to state privacy and confidentiality statutes, Chmara examines the varied state protection of library records. To allow readers to further access the relevant information, Chmara provides a fifty-state survey of confidentiality and privacy laws as an appendix. Although she emphasizes that the statutes in the Appendix must be updated and further researched, the Appendix is an efficient resource and informative starting point.

As an academic law librarian and legal research teacher, I enjoyed reading this text. It served as an excellent review of First Amendment principles as they apply to libraries. It also gave me greater insight into the daily functions of public libraries. First, with the installation of the computers and the Internet service in public libraries, librarians dealt with an assortment of challenges from members of the public viewing sensitive material on the Internet to creating Internet usage policies and monitoring the same. Similarly, since September 11, public libraries have been under greater scrutiny by law enforcement officials at local, state, and federal levels. Privacy and Confidentiality Issues: A Guide for Libraries and Their Lawyers offers digestible and practical guidance for libraries facing these challenges as well as reminds a more general audience of the enduring First Amendment principles protecting our libraries.

Julie Graves Krishnaswami is the Faculty Services Librarian and a Legal Research Professor at City University of New York School of Law (CUNY). 
Ads by Google

\section{HIPAA Compliance Data}

Endpoint Security for Every Device Compliance Proof and Daily Updates www.Credant.com/HIPAA

Ads by Google

\section{Whistleblower Complaint?}

Former feds will help you prove qui tam fraud. Nationwide Practice. www.JamesHoyer.com

Ads by Google

\section{Whistleblower Complaint?}

Former feds will help you prove qui tam fraud. Nationwide Practice. www.JamesHoyer.com

\section{Responses to "Book Review: Privacy and Confidentiality Issues: A Guide for Libraries and Their Lawyers"}

Leave a Comment 